\title{
Hemoglobin concentrations and adverse birth outcomes in South Asian pregnant women: findings from a prospective Maternal and Neonatal Health Registry
}

Sumera Aziz Ali ${ }^{1 *}$ D, Shiyam Sunder Tikmani ${ }^{1}$, Sarah Saleem¹, Archana B. Patel², Patricia L. Hibberd ${ }^{3}$, Shivaprasad S. Goudar ${ }^{4}$, Sangappa Dhaded ${ }^{4}$, Richard J. Derman', Janet L. Moore ${ }^{6}$, Elizabeth M. McClure ${ }^{6}$ and Robert L. Goldenberg ${ }^{7}$

From Global Network

Virtual. 3-15 Septemeber 2020

\begin{abstract}
Background: While the relationship between hemoglobin $(\mathrm{Hb})$ concentrations and pregnancy outcomes has been studied often, most reports have focused on a specific $\mathrm{Hb}$ cutoff used to define anemia. Fewer studies have evaluated pregnancy outcomes across the entire range of $\mathrm{Hb}$ values. Moreover, to date, most studies of the relationship of $\mathrm{Hb}$ concentrations to pregnancy outcomes have been done in high-income countries. Thus, we have sought to determine the relationship between the range of maternal $\mathrm{Hb}$ concentrations and adverse birth outcomes among South Asian pregnant women.
\end{abstract}

Methods: For this study, we used data collected from two South Asian countries (Pakistan - Sindh Province and two sites in India - Belagavi and Nagpur) in a prospective maternal and newborn health registry study. To assess the association between $\mathrm{Hb}$ concentrations and various maternal and fetal outcomes, we classified the $\mathrm{Hb}$ concentrations into seven categories. Regression analyses adjusting for multiple potential confounders were performed to assess adverse pregnancy outcomes across the range of $\mathrm{Hb}$ concentrations.

(Continued on next page)

*Correspondence: Sumeraaziz7@gmail.com

'Department of Community Health Sciences, Aga Khan University, Stadium Road, Karachi 74800, Pakistan

Full list of author information is available at the end of the article

C C The Author(s). 2020 Open Access This article is licensed under a Creative Commons Attribution 4.0 International License, which permits use, sharing, adaptation, distribution and reproduction in any medium or format, as long as you give appropriate credit to the original author(s) and the source, provide a link to the Creative Commons licence, and indicate if changes were made. The images or other third party material in this article are included in the article's Creative Commons licence, unless indicated otherwise in a credit line to the material. If material is not included in the article's Creative Commons licence and your intended use is not permitted by statutory regulation or exceeds the permitted use, you will need to obtain permission directly from the copyright holder. To view a copy of this licence, visit http://creativecommons.org/licenses/by/4.0/. The Creative Commons Public Domain Dedication waiver (http://creativecommons.org/publicdomain/zero/1.0/) applies to the data made available in this article, unless otherwise stated in a credit line to the data. 


\begin{abstract}
(Continued from previous page)
Findings: Between January 2012 and December 2018, 130,888 pregnant women were enrolled in the South Asian sites had a $\mathrm{Hb}$ measurement available, delivered and were included in the analyses. Overall, the mean $\mathrm{Hb}$ concentration of pregnant women from the sites was $9.9 \mathrm{~g} / \mathrm{dL}, 10.0 \mathrm{~g} / \mathrm{dL}$ in the Indian sites and $9.5 \mathrm{~g} / \mathrm{dL}$ in the Pakistan site. $\mathrm{Hb}$ concentrations $<7 \mathrm{~g} / \mathrm{dL}$ were observed in $6.9 \%$ of the pregnant Pakistani women and $0.2 \%$ of the Indian women. In both the Pakistani and Indian sites, women with higher parity and women with no formal education had lower $\mathrm{Hb}$ concentrations. In the Pakistani site, women $>35$ years of age, women with $\geq 4$ children and those who enrolled in the third trimester were more likely to have $\mathrm{Hb}$ concentrations of $<7 \mathrm{~g} / \mathrm{dL}$ but these associations were not found for the Indian sites. When adjusting for potential confounders, for both India and Pakistan, lower $\mathrm{Hb}$ concentrations were associated with stillbirth, preterm birth, lower mean birthweight, and increased risk of low birthweight. In the Pakistani site, there was evidence of a U-shaped relationship between $\mathrm{Hb}$ concentrations and low birth weight, and neonatal mortality, and in India with hypertensive disease.

Interpretation: This study documented the relationship between maternal $\mathrm{Hb}$ concentrations and adverse pregnancy outcomes in women from the Pakistani and Indian sites across the range of $\mathrm{Hb}$ values. Both low and high $\mathrm{Hb}$ concentrations were associated with risk of at least some adverse outcomes. Hence, both low and high values of $\mathrm{Hb}$ should be considered risk factors for the mother and fetus.
\end{abstract}

Keywords: Hemoglobin concetrations, Anemia, South Asia, India, Pakistan, Pregnancy outcome, Stillbirth, Neonatal mortality, Global network

\section{Background}

Anemia remains a significant health problem globally, accounting for more than 60,000 maternal deaths and 3.4\% of global disability-adjusted life years in women aged 1549 years [1]. According to the World Health Organization (WHO), globally, 528.7 million (29.4\%) women of reproductive age are anemic with a hemoglobin $(\mathrm{Hb})$ concentration of $<11 \mathrm{~g} / \mathrm{dL}$ [2]. Of these women, 20.2 million are defined as severely anemic with a $\mathrm{Hb}$ concentration of $<7$ $\mathrm{g} / \mathrm{dL}$ [2]. Rates of anemia are highest in low-resource countries, especially in central and west Africa where $48 \%$ of reproductive-age women and $56 \%$ of all pregnant women are reported to be anemic and in South Asia, where $47 \%$ of all reproductive-age women and $52 \%$ of pregnant women are reported to be anemic [2].

Multiple adverse maternal and neonatal outcomes have been attributed to anemia [3]. These outcomes vary according to the severity of anemia [4]. Reported maternal and perinatal outcomes among severely anemic women include premature rupture of membranes, preterm births (PTB), hypertensive diseases of pregnancy, puerperal pyrexia, fetal distress, small for gestational age, stillbirths, neonatal and maternal deaths [5]. Findings from systematic reviews and meta-analyses have also suggested that in low-income countries, $25 \%$ of low-birth weight (LBW), $44 \%$ of PTB, and $21 \%$ of perinatal mortality are attributable to anemia [6]. One review observed a relatively higher anemia-attributable proportion of LBW in Pakistan and Bangladesh compared to Ghana and India [6]. Similarly, the highest anemia-attributable proportion of PTB was observed in Pakistan (54\%) followed by India (27\%) and Iran (18\%) [6]. Further, studies have also revealed that women with low $\mathrm{Hb}$ concentrations during pregnancy are at higher risk of antepartum and postpartum hemorrhage, obstructed labor, and cesarean-section delivery when compared to the women with normal hemoglobin concentrations [7-10].

At the other end of the spectrum, several older studies have shown that elevated $\mathrm{Hb}$ concentrations during pregnancy are also associated with increased risk of adverse birth outcomes, including PTB, LBW, fetal death and intrauterine growth retardation [11-14]. However, the findings have not been consistent $[12,15]$. Moreover, this potential U-shaped relationship, with higher risks of adverse birth outcomes at both extremes of $\mathrm{Hb}$ concentrations have been assessed primarily in more developed countries such as the U.S., Sweden, and Iran [16-18]. Thus, very few studies have described the relationship between high $\mathrm{Hb}$ concentrations and birth outcomes in low-and middle-income countries (LMIC) and particularly in women from South Asia [11, 12]. Moreover, the relationship between higher concentrations of $\mathrm{Hb}$ with adverse outcomes, such as antepartum and postpartum hemorrhage, obstructed labor, and cesarean delivery is not explored in the literature.

The objective of this study was to assess the associations across the range of maternal $\mathrm{Hb}$ concentrations and adverse birth outcomes in South Asian pregnant women as well as evaluating factors related to $\mathrm{Hb}$ concentrations by country. Differences between the Pakistani and Indian sites in the relationship of $\mathrm{Hb}$ concentration and pregnancy outcomes were explored. An understanding of these outcomes and the association of $\mathrm{Hb}$ concentrations with adverse pregnancy outcomes is essential to inform policies to improve maternal and fetal/neonatal outcomes. 


\section{Methods}

The Global Network's Maternal Newborn Health Registry (MNHR) is a multi-site, prospective, ongoing, active surveillance system to track pregnancies and births in defined geographic communities (clusters), each with approximately 300 to 500 deliveries per year. The MNHR is funded by the Eunice Kennedy Shriver National Institute of Child Health and Human Development (NICHD) through grants to the NICHD Global Network for Women's and Children's Health (ClinicalTrials.gov Identifier: NCT01073475). The aim of the MNHR is to document birth outcomes in defined geographical areas and provide population-based rates of stillbirth, neonatal and maternal deaths, and other adverse outcomes. The details of the MNHR are described elsewhere [19].

For this study, we used data collected from the three South Asian sites (Pakistan - Sindh Province and two sites in central India - Belagavi and Nagpur). For purpose of analyses, we grouped the two Indian sites, which had similar demographics, and analyzed the Pakistan site separately. Since the MNHR began to collect maternal $\mathrm{Hb}$ concentrations in 2012, we included data of women who were enrolled between January 2012 and December 2018. However, the Pakistani site started routinely collecting $\mathrm{Hb}$ data in 2014. Those pregnant women who provided consent and had $\mathrm{Hb}$ measurements available at the enrollment visit were included. Women who delivered before 20 weeks, had a medical termination of pregnancy, were not residents of the study cluster or who had incomplete outcome data were excluded from this analysis (Fig. 1).

Gestational age was based on the best data available, usually the last menstrual period (LMP), although in the later years of the study, ultrasound was more widely used for gestational age determination. PTB was defined as births < 37 weeks' gestational age using a project specific algorithm. The gestational age of the first prenatal visit was used as a surrogate for the gestational age of the $\mathrm{Hb}$ determination, because $\mathrm{Hb}$ was generally measured at the first prenatal visit and we did not collect the specific gestational age $\mathrm{Hb}$ measurement separately. If more than one $\mathrm{Hb}$ measurement was recorded, only the first was used in this analysis. The inter-delivery interval was calculated by subtracting the date of the last delivery from the date of delivery of the current pregnancy and converting that time into months.

To assess the association between $\mathrm{Hb}$ concentrations and various maternal outcomes, (maternal mortality,

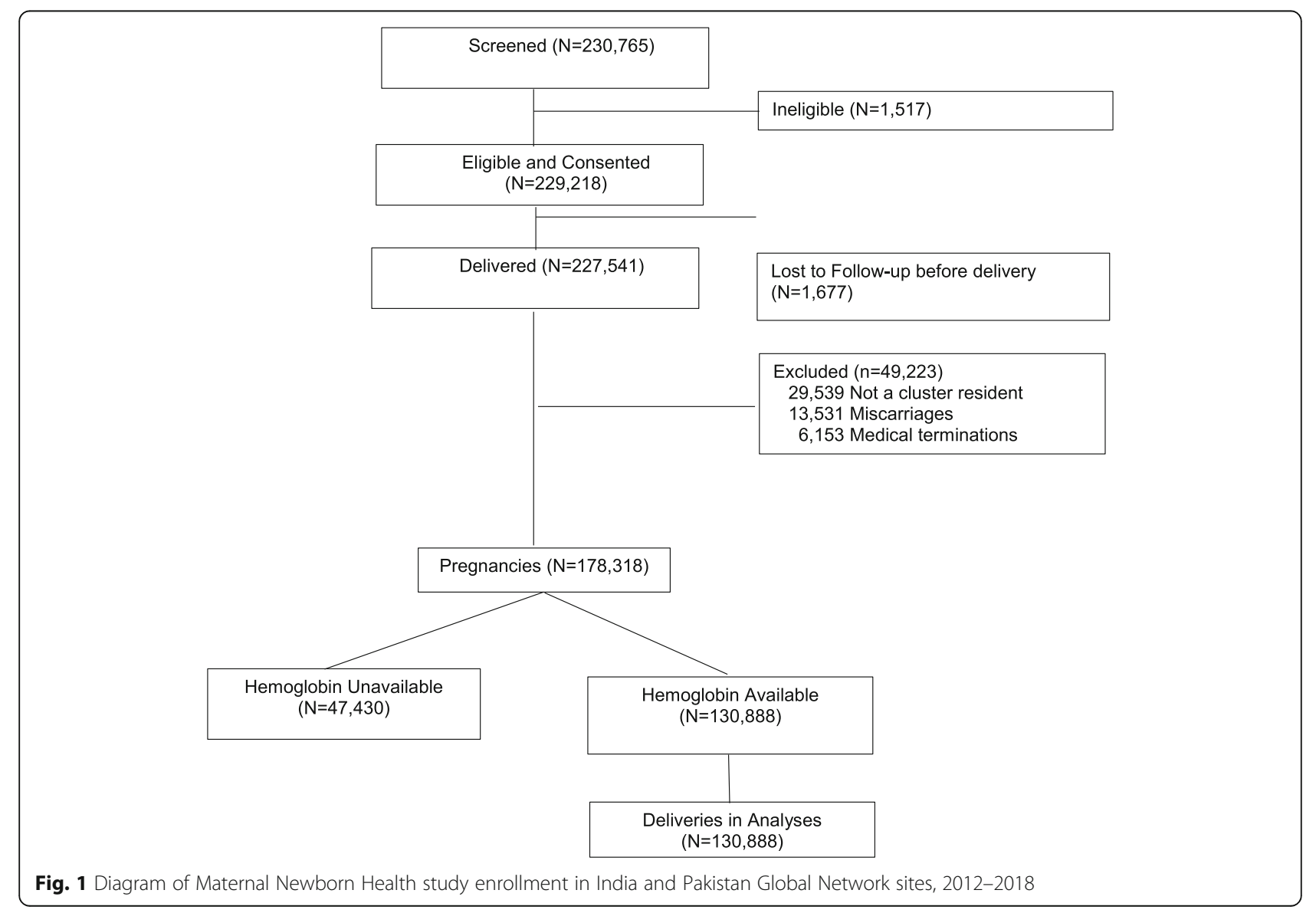


antepartum hemorrhage, postpartum hemorrhage, hypertensive disease of pregnancy/pre-eclampsia/eclampsia, obstructed labor and cesarean delivery) and fetal/neonatal outcomes (PTB, LBW, stillbirth and neonatal mortality), we classified the $\mathrm{Hb}$ concentrations into 7 categories, < $7.0 \mathrm{~g} / \mathrm{dL}, 7.0-7.9 \mathrm{~g} / \mathrm{dL}, 8.0-8.9 \mathrm{~g} / \mathrm{dL}, 9.0-9.9 \mathrm{~g} / \mathrm{dL}, 10.0-$ $10.9 \mathrm{~g} / \mathrm{dL}, 11.0-12.9 \mathrm{~g} / \mathrm{dL}$ and $\geq 13.0 \mathrm{~g} / \mathrm{dL}$. Values of 11.0 $12.9 \mathrm{~g} / \mathrm{dL}$ are generally considered normal ${ }^{17}$ and were used as the reference group for this study to assess the relationship of outcomes with other $\mathrm{Hb}$ categories.

Data were entered and edited at each study site prior to secure transmission to the central data center (RTI International) where further edits and statistical analyses were performed. We produced descriptive statistics stratified by country to examine the different concentrations of $\mathrm{Hb}$ for characteristics of pregnant women and used Cochran-Mantel-Haenszel tests stratified by study cluster to assess differences in hemoglobin concentrations among these characteristics. Generalized linear models adjusting for multiple potential maternal confounders and using generalized estimating equations to account for the correlation of outcomes within cluster were performed to assess the risk of adverse pregnancy outcomes across the range of $\mathrm{Hb}$ concentrations compared to the reference group separately for the Indian and Pakistani sites. In these models, we also adjusted for the gestational age at enrollment, as there may be confounding associated with gestational age of $\mathrm{Hb}$ measurement and outcomes. We then performed locally weighted scatterplot smoothing (LOESS), a nonparametric method for fitting a smooth curve to data points to picture the relationship between maternal $\mathrm{Hb}$ concentrations and four birth outcomes (birth weight, stillbirth, 7-day neonatal mortality and 28-day neonatal mortality).

This study was reviewed and approved by all sites' ethics review committees (Aga Khan University, Karachi, Pakistan; KLE Academy of Higher Education and Research, Belagavi, India; Lata Medical Research Foundation, Nagpur, India) and the corresponding U.S. partners (Boston University, Columbia University, Thomas Jefferson University, and RTI International). All women provided informed consent for participation in the study. The study was funded by grants from the U.S. National Institute of Child Health and Human Development.

\section{Results}

From the overall cohort in the India and Pakistan sites from 2012 to 2018, 230,765 women were screened (Fig. 1). Of these women, 229,218 (99.3\%) were eligible and consented to take part in the study. Of these pregnant women, 227,541 delivered, 68,590 from the Pakistan site and 158,951 from the two Indian sites. Of these, 49,223 women (6574 Pakistani and 42,649 Indian women) were excluded, because they were not residents of a study cluster $(29,539)$, had a miscarriage $(13,531)$, or had a medically terminated pregnancy (6153). Hence, a total of 178,318 deliveries were eligible for further analysis, 62,016 from the Pakistani site and 116,302 from the two Indian sites. Of these eligible deliveries, $\mathrm{Hb}$ data were available for 130 , 888 women, 18,154 from the Pakistani site and 112,734 from the Indian sites. In both countries, about half of the women were enrolled in the first trimester, about a third in the second trimester and the remainder in the third trimester or after delivery. Only about $1.5 \%$ of the women in both sites were enrolled after delivery (data not shown).

To assess whether the women for which we had $\mathrm{Hb}$ measurements were similar to those for which $\mathrm{Hb}$ measurements were not available, we compared the populations in Supplemental Table S1. While many of the differences were significant, the differences between the two groups were generally small and not likely clinically important.

Table 1 presents the $\mathrm{Hb}$ concentrations by country. The mean $\mathrm{Hb}$ concentration in the Indian sites was 10.0 g/dL (SD 1.0) and 9.5 g/dL (SD 1.7) in the Pakistani site. $6.9 \%$ of the pregnant Pakistani women and $0.2 \%$ of the Indian women had $\mathrm{Hb}$ concentrations of $<7.0 \mathrm{~g} / \mathrm{dL}$. $10.5 \%$ of Pakistani women had $\mathrm{Hb}$ concentrations from $7.0-7.9 \mathrm{~g} / \mathrm{dL}$ and $0.9 \%$ of Indian women were in this category. $18.6 \%$ of Pakistani women had $\mathrm{Hb}$ concentrations between $8.0-8.9 \mathrm{~g} / \mathrm{dL}$, while $7.1 \%$ of the Indian women had $\mathrm{Hb}$ concentrations in this category. Thus, we observed substantial differences in the percent of very low $\mathrm{Hb}$ values between women at the Pakistani and Indian sites. On the other hand, $20.5 \%$ of Pakistani women, compared to $38.6 \%$ of Indian women, had Hb concentrations of $10.0-10.9 \mathrm{~g} / \mathrm{dL} .16 .8 \%$ of Pakistani women and $14.3 \%$ of Indian women had $\mathrm{Hb}$ concentrations of 11.0$12.9 \mathrm{~g} / \mathrm{dL}$. Very few women had $\mathrm{Hb}$ concentrations of

Table 1 Hemoglobin concentrations among pregnant women in Indian and Pakistan Global Network study sites, 2012-2018

\begin{tabular}{llll}
\hline & Total & Pakistan & India \\
\hline Deliveries, N & 130,888 & 18,154 & 112,734 \\
Hemoglobin g/dL, N (\%) & & & \\
Very low $(<7.0)$ & $1523(1.2)$ & $1255(6.9)$ & $268(0.2)$ \\
Low (7.0-7.9) & $2903(2.2)$ & $1911(10.5)$ & $992(0.9)$ \\
Low (8.0-8.9) & $11,416(8.7)$ & $3379(18.6)$ & $8037(7.1)$ \\
Low (9.0-9.9) & $46,946(35.9)$ & $4486(24.7)$ & $42,460(37.7)$ \\
Low normal (10.0-10.9) & $47,245(36.1)$ & $3715(20.5)$ & $43,530(38.6)$ \\
Normal (11.0-12.9) & $19,217(14.7)$ & $3054(16.8)$ & $16,163(14.3)$ \\
High ( $\geq 13.0)$ & $1638(1.3)$ & $354(1.9)$ & $1284(1.1)$ \\
Hemoglobin mean (SD $)$ & $9.9(1.1)$ & $9.5(1.7)$ & $10.0(1.0)$ \\
\hline
\end{tabular}

${ }^{\mathrm{a}} \mathrm{SD}$ standard deviation 
$\geq 13.0 \mathrm{~g} / \mathrm{dL}$ in the Pakistani site $(1.9 \%)$ and in the Indian sites (1.1\%).

Tables 2 and 3 describe $\mathrm{Hb}$ concentrations by the socio-demographic and clinical characteristics of pregnant women for the Pakistani and Indian sites. In both sites, the percent of women $<20$ years of age was low, $4.2 \%$ in Pakistan and $6.7 \%$ in India. Women with a primary or higher level of education were much more common in the Indian site, $90.9 \%$ vs $17.1 \%$ in the Pakistani site. The percent of women with parity $>4$ was higher in Pakistan $31.2 \%$ vs $1.3 \%$ in India. Women enrolled in both countries tended to have a body mass index (BMI) $<18.5 \mathrm{~kg} / \mathrm{m}^{2}, 28.7 \%$ in Pakistan, and $37.0 \%$ in India.

In both the Pakistani and Indian sites, younger women and primiparous women were more likely to have normal or higher $\mathrm{Hb}$ concentrations, while women of higher parity were more likely to have lower $\mathrm{Hb}$ concentrations. In the Pakistani site, women $>35$ were also more likely to have lower $\mathrm{Hb}$ concentrations. Higher educated women in both sites tended to have normal $\mathrm{Hb}$ concentrations, while women with no formal education were more likely to have low $\mathrm{Hb}$ concentrations. In all of the sites, women with a BMI $\geq 25 \mathrm{~kg} / \mathrm{m}^{2}$ tended towards higher $\mathrm{Hb}$ concentrations, however in India only women $\mathrm{BMI}<18.5 \mathrm{~kg} / \mathrm{m}^{2}$ tended to have lower $\mathrm{Hb}$ concentrations of $8.0-9.9 \mathrm{~g} / \mathrm{dL}$. Multiple pregnancy was not statistically associated with $\mathrm{Hb}$ concentrations. In the Pakistani site, inter-delivery interval was not associated with $\mathrm{Hb}$ level. However, in the Indian sites, longer interdelivery intervals tended to be associated with a greater proportion of normal $\mathrm{Hb}$ concentrations. Gestational age at enrollment (and a proxy for the gestational age at which the $\mathrm{Hb}$ measurement was done) was associated with the $\mathrm{Hb}$ concentrations. In the Pakistani site, a higher proportion of women who enrolled late had lower $\mathrm{Hb}$ concentrations.

Tables 4 and 5 display the unadjusted rates of adverse maternal and fetal/neonatal outcomes overall and by $\mathrm{Hb}$ category. Maternal and neonatal mortality and stillbirth as well as the other adverse outcomes including antepartum and postpartum hemorrhage, PTB, and LBW were observed more often in the Pakistani site than in the Indian sites. Hypertensive disease/pre-eclampsia/eclampsia, obstructed labor and cesarean delivery were observed more often in the Indian sites than in the Pakistani site.

To determine the association of the $\mathrm{Hb}$ concentrations and the adverse outcomes, stratified by the Pakistani (Table 6) and the Indian sites (Table 7), we compared the risk of the adverse outcomes for each $\mathrm{Hb}$ category to the risk of those outcomes in women with a $\mathrm{Hb}$ concentration of $11.0-12.9 \mathrm{~g} / \mathrm{dL}$, our reference group. The risks of outcomes were adjusted for potential confounders including maternal age, education level, parity, BMI and gestational age at enrollment. Because maternal deaths were relatively rare, the models did not converge to produce estimates of risk for maternal mortality by $\mathrm{Hb}$ concentration for either site. For the Pakistani site, women with $\mathrm{Hb}$ concentrations $<7 \mathrm{~g} / \mathrm{dL}$ had a higher risk of antepartum hemorrhage compared to women with normal $\mathrm{Hb}$ concentrations; for post-partum hemorrhage, women with $\mathrm{Hb}$ concentrations $<7.9 \mathrm{~g} / \mathrm{dL}$ showed higher risk. $\mathrm{Hb}$ concentrations were not associated with hypertensive disease or obstructed labor. Compared to women with normal $\mathrm{Hb}$ concentrations, women with $\mathrm{Hb}$ concentrations $<11 \mathrm{~g} / \mathrm{dL}$ were less likely to have a cesarean delivery and had a higher risk for PTB. Stillbirths were generally more common in the groups with a $\mathrm{Hb}$ concentration $<10 \mathrm{~g} / \mathrm{dL}$, with 3 of the $4<10 \mathrm{~g} / \mathrm{dL} \mathrm{Hb}$ concentration groups having a statistically greater risk of stillbirth than the group with a $\mathrm{Hb}$ concentration of 11-12.9 $\mathrm{g} / \mathrm{dL}$. Neonatal mortality, whether at $<7$ days or $<28$ days, was higher in the groups with $\mathrm{Hb}$ concentrations $<7 \mathrm{~g} / \mathrm{dL}$ and in the women with a $\mathrm{Hb}$ concentration of $>13 \mathrm{~g} / \mathrm{dL}$, a $\mathrm{U}$-shaped relationship. Birthweight was lower in all the groups with a $\mathrm{Hb}$ concentration $<11 \mathrm{~g} / \mathrm{dL}$ compared to the reference group. LBW also had a U-shaped relationship with higher risk for $\mathrm{Hb}$ concentrations above and below 11.0 to $12.9 \mathrm{~g} / \mathrm{dL}$.

In the Indian sites, as in the Pakistani site, both antepartum and postpartum hemorrhage were associated with very low $(<7.0 \mathrm{~g} / \mathrm{dL}) \mathrm{Hb}$ concentrations. Hypertensive disease was more common in women with very low and very high $\mathrm{Hb}$ concentrations, suggesting a U-shaped relationship. Furthermore, women with a $\mathrm{Hb}$ of 10.0 $10.9 \mathrm{~g} / \mathrm{dL}$ had lower risk for hypertensive disease compared to $11.0-12.9 \mathrm{~g} / \mathrm{dL}$. Risk of obstructed labor and cesarean delivery was lower in the women with $\mathrm{Hb}$ values between 8 and $11 \mathrm{~g} / \mathrm{dL}$ and women with $\mathrm{Hb}$ values between 7 and $11 \mathrm{~g} / \mathrm{dL}$ were also at lower risk for cesarean delivery. Risk of stillbirth was generally higher in women with a $\mathrm{Hb}<10 \mathrm{~g} / \mathrm{dL}$ with the results significant in 3 of the $4 \mathrm{Hb}<10 \mathrm{~g} / \mathrm{dL}$ categories. Risk of PTB was higher for Indian women with $\mathrm{Hb}<10 \mathrm{~g} / \mathrm{dL}$. Similar to the Pakistani site, women with a $\mathrm{Hb}$ concentration of $<10 \mathrm{~g} / \mathrm{dL}$ had a higher risk of neonatal mortality, however women with a $\mathrm{Hg}$ concentration $\geq 13 \mathrm{~g} / \mathrm{dL}$ did not show increased risk as in the Pakistani site. In India, women with $\mathrm{Hb}$ concentrations $<9.0 \mathrm{~g} / \mathrm{dL}$ were at higher risk to have babies with LBW and women with $\mathrm{Hb}$ concentrations $<11.0 \mathrm{~g} / \mathrm{dL}$ were more likely to have babies weighing less than those with normal $\mathrm{Hb}$ concentrations. The LOESS plots (Fig. 2) illustrate the relationship between $\mathrm{Hb}$ concentrations and the outcomes of birthweight, stillbirth and 7 and 28-day mortality for the Indian and Pakistani sites. Figure 2 illustrates that there is a U-shaped relationship between hemoglobin concentrations and outcomes such as neonatal mortality and 
Table 2 Socio Demographic and Clinical Characteristics of Pregnant Women by Hemoglobin Concentration for Pakistan

\begin{tabular}{|c|c|c|c|c|c|c|c|c|c|}
\hline \multirow[t]{2}{*}{ Maternal Characteristics } & \multirow{2}{*}{$\begin{array}{l}\text { Overall }^{1} \\
\mathrm{~N}(\%)\end{array}$} & \multicolumn{7}{|c|}{ Maternal Hemoglobin $\mathrm{g} / \mathrm{dL}^{1}, \mathrm{~N}(\%)$} & \multirow{2}{*}{$\begin{array}{l}P \text { - } \\
\text { value }^{2}\end{array}$} \\
\hline & & $\begin{array}{l}\text { Very low( }< \\
7.0)\end{array}$ & $\begin{array}{l}\operatorname{Low}(7.0- \\
7.9)\end{array}$ & $\begin{array}{l}\operatorname{Low}(8.0- \\
8.9)\end{array}$ & $\begin{array}{l}\operatorname{Low}(9.0- \\
9.9)\end{array}$ & $\begin{array}{l}\text { Low } \\
\text { normal(10.0- } \\
10.9)\end{array}$ & $\begin{array}{l}\text { Normal(11.0- } \\
12.9)\end{array}$ & $\begin{array}{l}\operatorname{High}(\geq \\
13.0)\end{array}$ & \\
\hline Deliveries, $\mathrm{N}$ & 18,154 & $1255(6.9)$ & $\begin{array}{l}1911 \\
(10.5)\end{array}$ & $\begin{array}{l}3379 \\
(18.6)\end{array}$ & $\begin{array}{l}4486 \\
(24.7)\end{array}$ & $3715(20.5)$ & $3054(16.8)$ & $354(1.9)$ & \\
\hline Maternal age & & & & & & & & & $<.0001$ \\
\hline$<20$ & $757(4.2)$ & $19(2.5)$ & $79(10.4)$ & $108(14.3)$ & $161(21.3)$ & $171(22.6)$ & $195(25.8)$ & $24(3.2)$ & \\
\hline $20-35$ & $\begin{array}{l}16,240 \\
(89.5)\end{array}$ & $1115(6.9)$ & $\begin{array}{l}1669 \\
(10.3)\end{array}$ & $\begin{array}{l}3004 \\
(18.5)\end{array}$ & $\begin{array}{l}4003 \\
(24.6)\end{array}$ & $3356(20.7)$ & $2774(17.1)$ & $319(2.0)$ & \\
\hline$>35$ & $\begin{array}{l}1157 \\
(6.4)\end{array}$ & $121(10.5)$ & $163(14.1)$ & $267(23.1)$ & $322(27.8)$ & $188(16.2)$ & $85(7.3)$ & $11(1.0)$ & \\
\hline Education & & & & & & & & & $<.0001$ \\
\hline No formal education & $\begin{array}{l}15,042 \\
(82.9)\end{array}$ & $1160(7.7)$ & $\begin{array}{l}1716 \\
(11.4)\end{array}$ & $\begin{array}{l}2941 \\
(19.6)\end{array}$ & $\begin{array}{l}3775 \\
(25.1)\end{array}$ & $2972(19.8)$ & $2214(14.7)$ & $264(1.8)$ & \\
\hline Primary/Secondary & $\begin{array}{l}2838 \\
(15.6)\end{array}$ & $93(3.3)$ & $184(6.5)$ & $410(14.4)$ & $650(22.9)$ & $670(23.6)$ & $748(26.4)$ & $83(2.9)$ & \\
\hline University+ & $274(1.5)$ & $2(0.7)$ & $11(4.0)$ & $28(10.2)$ & $61(22.3)$ & $73(26.6)$ & $92(33.6)$ & $7(2.6)$ & \\
\hline Parity & & & & & & & & & $<.0001$ \\
\hline 0 & $\begin{array}{l}3766 \\
(21.0)\end{array}$ & $135(3.6)$ & $333(8.8)$ & $545(14.5)$ & $813(21.6)$ & $887(23.6)$ & $944(25.1)$ & $109(2.9)$ & \\
\hline $1-3$ & $\begin{array}{l}8551 \\
(47.8)\end{array}$ & $569(6.7)$ & $833(9.7)$ & $\begin{array}{l}1586 \\
(18.5)\end{array}$ & $\begin{array}{l}2274 \\
(26.6)\end{array}$ & $1766(20.7)$ & $1362(15.9)$ & $161(1.9)$ & \\
\hline$\geq 4$ & $\begin{array}{l}5588 \\
(31.2)\end{array}$ & $531(9.5)$ & $725(13.0)$ & $\begin{array}{l}1221 \\
(21.9)\end{array}$ & $\begin{array}{l}1347 \\
(24.1)\end{array}$ & $1001(17.9)$ & $687(12.3)$ & $76(1.4)$ & \\
\hline BMI & & & & & & & & & $<.0001$ \\
\hline$<18.5$ & $\begin{array}{l}5206 \\
(28.7)\end{array}$ & $390(7.5)$ & $577(11.1)$ & $987(19.0)$ & $\begin{array}{l}1215 \\
(23.3)\end{array}$ & $1031(19.8)$ & $889(17.1)$ & $117(2.2)$ & \\
\hline $18.5-25$ & $\begin{array}{l}10,794 \\
(59.5)\end{array}$ & $769(7.1)$ & $\begin{array}{l}1185 \\
(11.0)\end{array}$ & $\begin{array}{l}2085 \\
(19.3)\end{array}$ & $\begin{array}{l}2735 \\
(25.3)\end{array}$ & $2161(20.0)$ & 1685 (15.6) & $174(1.6)$ & \\
\hline$\geq 25$ & $\begin{array}{l}2140 \\
(11.8)\end{array}$ & $95(4.4)$ & $147(6.9)$ & $306(14.3)$ & $528(24.7)$ & $523(24.4)$ & $478(22.3)$ & $63(2.9)$ & \\
\hline Multiple pregnancy & & & & & & & & & 0.3639 \\
\hline Yes & $194(1.1)$ & $13(6.7)$ & $24(12.4)$ & 38 (19.6) & $44(22.7)$ & $40(20.6)$ & $30(15.5)$ & $5(2.6)$ & \\
\hline No & $\begin{array}{l}17,906 \\
(98.9)\end{array}$ & $1231(6.9)$ & $\begin{array}{l}1881 \\
(10.5)\end{array}$ & $\begin{array}{l}3335 \\
(18.6)\end{array}$ & $\begin{array}{l}4433 \\
(24.8)\end{array}$ & $3668(20.5)$ & $3014(16.8)$ & $344(1.9)$ & \\
\hline $\begin{array}{l}\text { Gestational age at } \\
\text { enrollment }\end{array}$ & & & & & & & & & $<.0001$ \\
\hline 1st trimester $(<13,0)$ & $\begin{array}{l}8015 \\
(45.2)\end{array}$ & $371(4.6)$ & $675(8.4)$ & $\begin{array}{l}1286 \\
(16.0)\end{array}$ & $\begin{array}{l}1817 \\
(22.7)\end{array}$ & $1758(21.9)$ & $1875(23.4)$ & $233(2.9)$ & \\
\hline 2nd trimester $(13,0-23,6)$ & $\begin{array}{l}5547 \\
(31.3)\end{array}$ & $434(7.8)$ & $616(11.1)$ & $\begin{array}{l}1071 \\
(19.3)\end{array}$ & $\begin{array}{l}1393 \\
(25.1)\end{array}$ & $1163(21.0)$ & $786(14.2)$ & $84(1.5)$ & \\
\hline $\begin{array}{l}\text { 3rd trimester/after } \\
\text { delivery }(\geq 24,0)\end{array}$ & $\begin{array}{l}4166 \\
(23.5)\end{array}$ & $382(9.2)$ & $557(13.4)$ & $938(22.5)$ & $\begin{array}{l}1178 \\
(28.3)\end{array}$ & $719(17.3)$ & $358(8.6)$ & $34(0.8)$ & \\
\hline Inter-delivery interval, N (\%) & & & & & & & & & 0.3340 \\
\hline$\leq 12$ months & $569(4.1)$ & $51(9.0)$ & $70(12.3)$ & $101(17.8)$ & $161(28.3)$ & $93(16.3)$ & 79 (13.9) & $14(2.5)$ & \\
\hline $12-24$ months & $\begin{array}{l}5263 \\
(37.6)\end{array}$ & $393(7.5)$ & $561(10.7)$ & $\begin{array}{l}1083 \\
(20.6)\end{array}$ & $\begin{array}{l}1316 \\
(25.0)\end{array}$ & $1068(20.3)$ & $765(14.5)$ & $77(1.5)$ & \\
\hline$>24$ months & $\begin{array}{l}8169 \\
(58.3)\end{array}$ & $639(7.8)$ & $913(11.2)$ & $\begin{array}{l}1606 \\
(19.7)\end{array}$ & $\begin{array}{l}2116 \\
(25.9)\end{array}$ & $1570(19.2)$ & $1181(14.5)$ & $144(1.8)$ & \\
\hline
\end{tabular}

${ }^{1}$ The overall column displays $\%$ of each characteristic, while the hemoglobin columns display $\%$ of each hemoglobin category within each maternal characteristic subgroup

${ }^{2} P$-values based on a Cochran-Mantel-Haenszel test for row mean differences based on standard mid-rank (modridit) scores stratified by cluster 
Table 3 Socio Demographic and Clinical Characteristics of Pregnant Women by Hemoglobin Concentration for India

\begin{tabular}{|c|c|c|c|c|c|c|c|c|c|}
\hline \multirow[t]{2}{*}{ Maternal Characteristics } & \multirow{2}{*}{$\begin{array}{l}\text { Overall }^{1} \\
\text { N (\%) }\end{array}$} & \multicolumn{7}{|c|}{ Maternal Hemoglobin $\mathrm{g} / \mathrm{dL}^{1}, \mathrm{~N}(\%)$} & \multirow{2}{*}{$\begin{array}{l}P \text { - } \\
\text { value }^{2}\end{array}$} \\
\hline & & $\begin{array}{l}\text { Very low }(< \\
7.0)\end{array}$ & $\begin{array}{l}\operatorname{Low}(7.0- \\
7.9)\end{array}$ & $\begin{array}{l}\operatorname{Low}(8.0- \\
8.9)\end{array}$ & $\begin{array}{l}\text { Low(9.0- } \\
9.9)\end{array}$ & $\begin{array}{l}\text { Low } \\
\text { normal(10.0- } \\
10.9)\end{array}$ & $\begin{array}{l}\text { Normal(11.0- } \\
12.9)\end{array}$ & $\begin{array}{l}\operatorname{High}(\geq \\
13.0)\end{array}$ & \\
\hline Deliveries, $N$ & 112,734 & $268(0.2)$ & $992(0.9)$ & $8037(7.1)$ & $\begin{array}{l}42,460 \\
(37.7)\end{array}$ & $43,530(38.6)$ & $16,163(14.3)$ & $1284(1.1)$ & \\
\hline Maternal age, N (\%) & & & & & & & & & $<.0001$ \\
\hline$<20$ & $7496(6.7)$ & $31(0.4)$ & $81(1.1)$ & $488(6.5)$ & $\begin{array}{l}2470 \\
(33.0)\end{array}$ & $2684(35.8)$ & $1522(20.3)$ & $220(2.9)$ & \\
\hline $20-35$ & $\begin{array}{l}104,760 \\
(93.0)\end{array}$ & $236(0.2)$ & $908(0.9)$ & $7504(7.2)$ & $\begin{array}{l}39,835 \\
(38.0)\end{array}$ & $40,651(38.8)$ & $14,565(13.9)$ & $1061(1.0)$ & \\
\hline$>35$ & $446(0.4)$ & $1(0.2)$ & $3(0.7)$ & $41(9.2)$ & $138(30.9)$ & $186(41.7)$ & $74(16.6)$ & $3(0.7)$ & \\
\hline Education, N (\%) & & & & & & & & & $<.0001$ \\
\hline No formal education & $\begin{array}{l}10,249 \\
(9.1)\end{array}$ & $67(0.7)$ & $143(1.4)$ & $1005(9.8)$ & $\begin{array}{l}4165 \\
(40.6)\end{array}$ & $3582(34.9)$ & $1184(11.6)$ & $103(1.0)$ & \\
\hline Primary/Secondary & $\begin{array}{l}86,809 \\
(77.1)\end{array}$ & $175(0.2)$ & $761(0.9)$ & $6295(7.3)$ & $\begin{array}{l}33,485 \\
(38.6)\end{array}$ & $33,306(38.4)$ & $11,834(13.6)$ & $953(1.1)$ & \\
\hline University+ & $\begin{array}{l}15,551 \\
(13.8)\end{array}$ & $26(0.2)$ & $84(0.5)$ & $731(4.7)$ & $\begin{array}{l}4766 \\
(30.6)\end{array}$ & $6586(42.4)$ & $3130(20.1)$ & $228(1.5)$ & \\
\hline Parity, N (\%) & & & & & & & & & $<.0001$ \\
\hline 0 & $\begin{array}{l}49,929 \\
(44.4)\end{array}$ & $124(0.2)$ & $397(0.8)$ & $3090(6.2)$ & $\begin{array}{l}17,386 \\
(34.8)\end{array}$ & $19,867(39.8)$ & $8332(16.7)$ & $733(1.5)$ & \\
\hline $1-3$ & $\begin{array}{l}61,118 \\
(54.3)\end{array}$ & $138(0.2)$ & $561(0.9)$ & $4734(7.7)$ & $\begin{array}{l}24,366 \\
(39.9)\end{array}$ & $23,133(37.8)$ & $7647(12.5)$ & $539(0.9)$ & \\
\hline$\geq 4$ & $1432(1.3)$ & $6(0.4)$ & $31(2.2)$ & $206(14.4)$ & $598(41.8)$ & $424(29.6)$ & $157(11.0)$ & $10(0.7)$ & \\
\hline BMI, N (\%) & & & & & & & & & $<.0001$ \\
\hline$<18.5$ & $\begin{array}{l}41,555 \\
(37.0)\end{array}$ & $114(0.3)$ & $427(1.0)$ & $3854(9.3)$ & $\begin{array}{l}17,408 \\
(41.9)\end{array}$ & $14,622(35.2)$ & $4746(11.4)$ & $384(0.9)$ & \\
\hline $18.5-25$ & $\begin{array}{l}64,980 \\
(57.9)\end{array}$ & $147(0.2)$ & $532(0.8)$ & $3932(6.1)$ & $\begin{array}{l}23,519 \\
(36.2)\end{array}$ & $26,312(40.5)$ & $9809(15.1)$ & $729(1.1)$ & \\
\hline$\geq 25$ & $5753(5.1)$ & $6(0.1)$ & $26(0.5)$ & $223(3.9)$ & $\begin{array}{l}1358 \\
(23.6)\end{array}$ & $2397(41.7)$ & $1573(27.3)$ & $170(3.0)$ & \\
\hline Multiple pregnancy, N (\%) & & & & & & & & & 0.2983 \\
\hline Yes & $991(0.9)$ & $1(0.1)$ & $14(1.4)$ & $77(7.8)$ & $382(38.5)$ & $356(35.9)$ & $152(15.3)$ & $9(0.9)$ & \\
\hline No & $\begin{array}{l}111,596 \\
(99.1)\end{array}$ & $266(0.2)$ & $978(0.9)$ & $7943(7.1)$ & $\begin{array}{l}42,022 \\
(37.7)\end{array}$ & $43,116(38.6)$ & $15,998(14.3)$ & $1273(1.1)$ & \\
\hline $\begin{array}{l}\text { Gestational age at } \\
\text { enrollment, N (\%) }\end{array}$ & & & & & & & & & $<.0001$ \\
\hline 1st trimester $(<13,0)$ & $\begin{array}{l}59,855 \\
(53.3)\end{array}$ & $133(0.2)$ & $494(0.8)$ & $4305(7.2)$ & $\begin{array}{l}22,355 \\
(37.3)\end{array}$ & $21,711(36.3)$ & $9771(16.3)$ & $1086(1.8)$ & \\
\hline 2nd trimester $(13,0-23,6)$ & $\begin{array}{l}38,536 \\
(34.3)\end{array}$ & $94(0.2)$ & $366(0.9)$ & $2794(7.3)$ & $\begin{array}{l}15,180 \\
(39.4)\end{array}$ & $15,504(40.2)$ & $4458(11.6)$ & $140(0.4)$ & \\
\hline $\begin{array}{l}\text { 3rd trimester/after } \\
\text { delivery }(\geq 24,0)\end{array}$ & $\begin{array}{l}13,953 \\
(12.4)\end{array}$ & $39(0.3)$ & $127(0.9)$ & $914(6.6)$ & $\begin{array}{l}4795 \\
(34.4)\end{array}$ & $6168(44.2)$ & $1863(13.4)$ & $47(0.3)$ & \\
\hline Inter-delivery interval, N (\%) & & & & & & & & & $<.0001$ \\
\hline$\leq 12$ months & $903(2.4)$ & $4(0.4)$ & $15(1.7)$ & $76(8.4)$ & $347(38.4)$ & $330(36.5)$ & $122(13.5)$ & $9(1.0)$ & \\
\hline 12-24 months & $\begin{array}{l}10,799 \\
(28.9)\end{array}$ & $20(0.2)$ & $109(1.0)$ & $893(8.3)$ & $\begin{array}{l}4339 \\
(40.2)\end{array}$ & $3725(34.5)$ & $1563(14.5)$ & $150(1.4)$ & \\
\hline$>24$ months & $\begin{array}{l}25,662 \\
(68.7)\end{array}$ & $75(0.3)$ & $252(1.0)$ & $1857(7.2)$ & $\begin{array}{l}9461 \\
(36.9)\end{array}$ & $9747(38.0)$ & $3938(15.3)$ & $332(1.3)$ & \\
\hline
\end{tabular}

${ }^{1}$ The overall column displays $\%$ of each characteristic, while the hemoglobin columns display $\%$ of each hemoglobin category within each maternal characteristic subgroup

${ }^{2} P$-values based on a Cochran-Mantel-Haenszel test for row mean differences based on standard mid-rank (modridit) scores stratified by cluster 
Table 4 Maternal and Fetal/Neonatal Outcomes by Hemoglobin Concentration for Pakistan

\begin{tabular}{|c|c|c|c|c|c|c|c|c|}
\hline & \multirow[t]{2}{*}{ Overall } & \multicolumn{7}{|c|}{ Maternal Hemoglobin g/dL } \\
\hline & & $\begin{array}{l}\text { Very } \operatorname{low}(< \\
7.0)\end{array}$ & $\begin{array}{l}\text { Low(7.0- } \\
7.9)\end{array}$ & $\begin{array}{l}\operatorname{Low}(8.0- \\
8.9)\end{array}$ & $\begin{array}{l}\operatorname{Low}(9.0- \\
9.9)\end{array}$ & $\begin{array}{l}\text { Low } \\
\text { normal(10.0- } \\
10.9)\end{array}$ & $\begin{array}{l}\text { Normal(11.0- } \\
12.9)\end{array}$ & $\begin{array}{l}\operatorname{High}(\geq \\
13.0)\end{array}$ \\
\hline \multicolumn{9}{|l|}{ Maternal Outcomes } \\
\hline Deliveries, $N$ & 18,154 & 1255 & 1911 & 3379 & 4486 & 3715 & 3054 & 354 \\
\hline $\begin{array}{l}\text { Maternal death }<42 \text { days(Rate/100,000 } \\
\text { deliveries) }\end{array}$ & $65(359)$ & $8(641)$ & $10(524)$ & $16(475)$ & $8(179)$ & $11(297)$ & $9(296)$ & $3(847)$ \\
\hline Antepartum hemorrhage, N (\%) & $\begin{array}{l}371 \\
(2.0)\end{array}$ & $44(3.5)$ & $34(1.8)$ & $74(2.2)$ & $80(1.8)$ & $77(2.1)$ & $54(1.8)$ & $8(2.3)$ \\
\hline Postpartum hemorrhage, N (\%) & $\begin{array}{l}479 \\
(2.6)\end{array}$ & $47(3.8)$ & $64(3.4)$ & $89(2.6)$ & $116(2.6)$ & $93(2.5)$ & $57(1.9)$ & $13(3.7)$ \\
\hline $\begin{array}{l}\text { Hypertensive disease/pre- eclampsia/ } \\
\text { eclampsia, N (\%) }\end{array}$ & $\begin{array}{l}481 \\
(2.7)\end{array}$ & $34(2.7)$ & $44(2.3)$ & $82(2.4)$ & $114(2.5)$ & $95(2.6)$ & $99(3.2)$ & $13(3.7)$ \\
\hline Obstructed labor, N (\%) & $\begin{array}{l}1275 \\
(7.0)\end{array}$ & $87(6.9)$ & $124(6.5)$ & $215(6.4)$ & $269(6.0)$ & $274(7.4)$ & $271(8.9)$ & $35(9.9)$ \\
\hline C-delivery, N (\%) & $\begin{array}{l}2713 \\
(15.0)\end{array}$ & $104(8.3)$ & $173(9.1)$ & $390(11.5)$ & $644(14.4)$ & $649(17.5)$ & $670(22.0)$ & $83(23.5)$ \\
\hline Preterm, N (\%) & $\begin{array}{l}4670 \\
(25.8)\end{array}$ & $405(32.3)$ & $536(28.2)$ & $883(26.2)$ & $\begin{array}{l}1161 \\
(25.9)\end{array}$ & $933(25.1)$ & $669(21.9)$ & $83(23.5)$ \\
\hline \multicolumn{9}{|l|}{ Fetal/Neonatal Outcomes } \\
\hline Births, N & 18,354 & 1269 & 1936 & 3420 & 4531 & 3755 & 3084 & 359 \\
\hline Stillbirth, N (Rate/1000) & $\begin{array}{l}889 \\
(48.5)\end{array}$ & $105(82.9)$ & $115(59.6)$ & $163(47.7)$ & $208(45.9)$ & $162(43.2)$ & $118(38.3)$ & $18(50.3)$ \\
\hline $\begin{array}{l}\text { Neonatal mortality }<7 \text { days, N (Rate/ } \\
\text { 1000) }\end{array}$ & $\begin{array}{l}709 \\
(40.7)\end{array}$ & $61(52.8)$ & $79(43.6)$ & $131(40.3)$ & $183(42.4)$ & $121(33.8)$ & $113(38.2)$ & $21(61.8)$ \\
\hline $\begin{array}{l}\text { Neonatal mortality < } 28 \text { days, N (Rate/ } \\
\text { 1000) }\end{array}$ & $\begin{array}{l}889 \\
(51.1)\end{array}$ & $80(69.2)$ & $101(55.7)$ & $169(52.0)$ & $222(51.5)$ & $157(43.8)$ & $137(46.4)$ & $23(67.6)$ \\
\hline Birth weight $(g)^{a}$, Mean (SD) & $\begin{array}{l}2702 \\
(491)\end{array}$ & $2587(523)$ & $\begin{array}{l}2672 \\
(491)\end{array}$ & $\begin{array}{l}2687 \\
(493)\end{array}$ & $\begin{array}{l}2702 \\
(488)\end{array}$ & $2727(476)$ & $2754(482)$ & $\begin{array}{l}2705 \\
(545)\end{array}$ \\
\hline Low birth weight $(<2500 \mathrm{~g})^{a}$, N (\%) & $\begin{array}{l}3950 \\
(22.2)\end{array}$ & $367(30.7)$ & $455(24.6)$ & $772(23.2)$ & $929(21.1)$ & $752(20.6)$ & $586(19.6)$ & $89(25.9)$ \\
\hline
\end{tabular}

${ }^{\mathrm{a} B i r t h}$ weight measured within 7 days of delivery

stillbirth for Pakistan. The relationship between hemoglobin concentrations and birth weight by site showed that both correlations were positive and significantly different from zero, but not high (Pakistan: $\mathrm{R}^{2}=$ $0.073, p<0.0001$ and India: $\left.\mathrm{R}^{2}=0.049, p<0.0001\right)$.

\section{Discussion}

This study had several important findings. First, although India and Pakistan originally were part of the same country and separated only about 70 years ago, the populations we studied are quite different in a number of demographic characteristics. The Pakistani population studied was far less educated and much more likely to have a higher parity than the Indian population. Both populations had high numbers of women with a low BMI although the Pakistani population had twice the rate of obese women $\left(\mathrm{BMI}>25 \mathrm{~kg} / \mathrm{m}^{2}\right)$. Low $\mathrm{Hb}$ concentrations were common in both populations although the proportion of women with very low $\mathrm{Hb}$ concentrations was much higher in Pakistan.

The relationships between maternal $\mathrm{Hb}$ concentrations and adverse outcomes were generally similar between the Pakistani and India sites, although there were differences. Antepartum and post-partum hemorrhage and stillbirth were associated with low $\mathrm{Hb}$ concentrations in enrolled women in both countries. Cesarean delivery also occurred less frequently at the lower $\mathrm{Hb}$ concentrations for both sites. Lower $\mathrm{Hb}$ concentrations were also associated with lower risk of obstructed labor in India. Hypertensive disease was not associated with $\mathrm{Hb}$ concentrations in the Pakistani site but was associated with a U-shaped relationship with $\mathrm{Hb}$ concentrations in India. In both populations, LBW was more common and low mean birthweight were always more common at the lowest $\mathrm{Hb}$ concentrations. In the Pakistani site, LBW tended to occur more often at the highest $\mathrm{Hb}$ concentrations as well. Seven and 28day neonatal mortality was more common at the lower $\mathrm{Hb}$ concentrations, and in the Pakistani site, there was a U-shaped relationship with both high and low $\mathrm{Hb}$. 
Table 5 Maternal and Fetal/Neonatal Outcomes by Hemoglobin Concentration for India

\begin{tabular}{|c|c|c|c|c|c|c|c|c|}
\hline & \multirow[t]{2}{*}{ Overall } & \multicolumn{7}{|c|}{ Maternal Hemoglobin g/dL } \\
\hline & & $\begin{array}{l}\text { Very low }(< \\
7.0)\end{array}$ & $\begin{array}{l}\text { Low(7.0- } \\
7.9)\end{array}$ & $\begin{array}{l}\operatorname{Low}(8.0- \\
8.9)\end{array}$ & $\begin{array}{l}\text { Low(9.0- } \\
9.9)\end{array}$ & $\begin{array}{l}\text { Low } \\
\text { normal(10.0- } \\
10.9)\end{array}$ & $\begin{array}{l}\text { Normal(11.0- } \\
12.9)\end{array}$ & $\begin{array}{l}\operatorname{High}(\geq \\
13.0)\end{array}$ \\
\hline \multicolumn{9}{|l|}{ Maternal Outcomes } \\
\hline Deliveries, N & 112,734 & 268 & 992 & 8037 & 42,460 & 43,530 & 16,163 & 1284 \\
\hline $\begin{array}{l}\text { Maternal death }<42 \text { days (Rate/100, } \\
000 \text { deliveries) }\end{array}$ & $\begin{array}{l}134 \\
(119)\end{array}$ & $0(0)$ & $1(101)$ & $18(224)$ & $41(97)$ & $47(108)$ & $23(142)$ & $4(312)$ \\
\hline Antepartum hemorrhage, N (\%) & $739(0.7)$ & $6(2.2)$ & $11(1.1)$ & $60(0.7)$ & $301(0.7)$ & $239(0.5)$ & $114(0.7)$ & $8(0.6)$ \\
\hline Postpartum hemorrhage, N (\%) & $679(0.6)$ & $10(3.8)$ & $14(1.4)$ & $70(0.9)$ & $209(0.5)$ & $233(0.5)$ & $131(0.8)$ & $12(1.0)$ \\
\hline $\begin{array}{l}\text { Hypertensive disease/pre- eclampsia/ } \\
\text { eclampsia, N (\%) }\end{array}$ & $\begin{array}{l}3685 \\
(3.3)\end{array}$ & $18(6.7)$ & $38(3.8)$ & $255(3.2)$ & $1287(3.0)$ & $1314(3.0)$ & $675(4.2)$ & $98(7.6)$ \\
\hline Obstructed labor, N (\%) & $\begin{array}{l}11,546 \\
(10.3)\end{array}$ & $27(10.1)$ & $90(9.1)$ & 749 (9.3) & $3970(9.4)$ & $4557(10.5)$ & $1982(12.3)$ & $171(13.3)$ \\
\hline C-delivery, N (\%) & $\begin{array}{l}28,706 \\
(25.5)\end{array}$ & $64(23.9)$ & $203(20.5)$ & $\begin{array}{l}1766 \\
(22.0)\end{array}$ & $\begin{array}{l}9664 \\
(22.8)\end{array}$ & $11,412(26.2)$ & $5172(32.0)$ & $425(33.1)$ \\
\hline Preterm, N (\%) & $\begin{array}{l}12,740 \\
(11.3)\end{array}$ & $43(16.2)$ & $141(14.2)$ & $\begin{array}{l}1050 \\
(13.1)\end{array}$ & $\begin{array}{l}5060 \\
(12.0)\end{array}$ & $4629(10.7)$ & $1676(10.4)$ & $141(11.0)$ \\
\hline \multicolumn{9}{|l|}{ Fetal/Neonatal Outcomes } \\
\hline Births, N & 113,749 & 269 & 1006 & 8116 & 42,853 & 43,893 & 16,319 & 1293 \\
\hline Stillbirth, N (Rate/1000) & $\begin{array}{l}2926 \\
(25.7)\end{array}$ & $15(55.8)$ & $36(35.8)$ & $245(30.2)$ & $\begin{array}{l}1166 \\
(27.2)\end{array}$ & $1038(23.7)$ & $392(24.0)$ & $34(26.3)$ \\
\hline $\begin{array}{l}\text { Neonatal mortality }<7 \text { days, N (Rate/ } \\
\text { 1000) }\end{array}$ & $\begin{array}{l}2097 \\
(18.9)\end{array}$ & $10(39.4)$ & $30(31.0)$ & $182(23.1)$ & $856(20.6)$ & $732(17.1)$ & $266(16.7)$ & $21(16.7)$ \\
\hline $\begin{array}{l}\text { Neonatal mortality < } 28 \text { days, N (Rate/ } \\
\text { 1000) }\end{array}$ & $\begin{array}{l}2593 \\
(23.4)\end{array}$ & $12(47.2)$ & $33(34.1)$ & $228(29.0)$ & $\begin{array}{l}1038 \\
(24.9)\end{array}$ & $926(21.6)$ & $328(20.6)$ & $28(22.3)$ \\
\hline Birth weight $(g)^{a}$, Mean (SD) & $\begin{array}{l}2707 \\
(462)\end{array}$ & $2641(505)$ & $\begin{array}{l}2644 \\
(481)\end{array}$ & $\begin{array}{l}2670 \\
(472)\end{array}$ & $\begin{array}{l}2687 \\
(466)\end{array}$ & $2720(450)$ & $2744(469)$ & $\begin{array}{l}2728 \\
(462)\end{array}$ \\
\hline Low birth weight $(<2500 \mathrm{~g})^{\mathrm{a}}, \mathrm{N}(\%)$ & $\begin{array}{l}21,575 \\
(19.2)\end{array}$ & $69(26.6)$ & $253(25.7)$ & $\begin{array}{l}1783 \\
(22.3)\end{array}$ & $\begin{array}{l}8436 \\
(20.0)\end{array}$ & $7787(18.0)$ & $2969(18.5)$ & $278(21.9)$ \\
\hline
\end{tabular}

${ }^{\text {aBirth }}$ weight measured within 7 days of delivery

There are several mechanisms through which low and high $\mathrm{Hb}$ concentrations may be associated with adverse fetal, neonatal, and maternal outcomes. For example, the underlying cause of low $\mathrm{Hb}$ concentrations is most often due to iron or vitamin deficiency resulting in impaired transport of oxygen to the uterus, placenta, and fetus. This mechanism might explain the increase in preterm birth, low birth weight and perinatal deaths associated with low $\mathrm{Hb}$ [20]. On the other hand, the association of high $\mathrm{Hb}$ concentrations with adverse outcomes might be due to other mechanisms. Higher $\mathrm{Hb}$ concentrations may not be a marker for increased red cell production, but instead may be a result of failure for the plasma volume to expand. The literature suggests that failure of the $\mathrm{Hb}$ concentrations to fall is associated with up to a threefold increased risk of pre-eclampsia and the birth of small for gestational age infants and preterm delivery [21-24]. Thus, an elevated $\mathrm{Hb}$ level is an indicator for possible pregnancy complications associated with poor plasma volume expansion, and should not be mistaken for good iron status [16].
Furthermore, it has been suggested that high $\mathrm{Hb}$ concentrations may restrict intrauterine growth as a consequence of high blood viscosity [14]. The increased viscosity related to low uterine arterial blood flow results in reduced oxygen delivery to the fetus. Thus, extremes of $\mathrm{Hb}$ concentrations during pregnancy appear to be associated with an increase in adverse outcomes. This issue may be an important consideration for setting standards for appropriate $\mathrm{Hb}$ concentrations during pregnancy. This $\mathrm{U}$-shaped relationship of $\mathrm{Hb}$ concentrations has been found with adverse outcomes such as stillbirth, preterm birth, and LBW in more developed countries $[11,16]$. Hence, through the present study, we were able to confirm evidence of a U-shaped relationship between $\mathrm{Hb}$ concentration and several adverse pregnancy outcomes among South Asian pregnant women.

\section{Strengths and limitations}

One of the biggest strengths of our study is the size of the cohort. To our knowledge, this is the largest cohort study that looked specifically at the extremes of $\mathrm{Hb}$ concentrations and its association with maternal and 


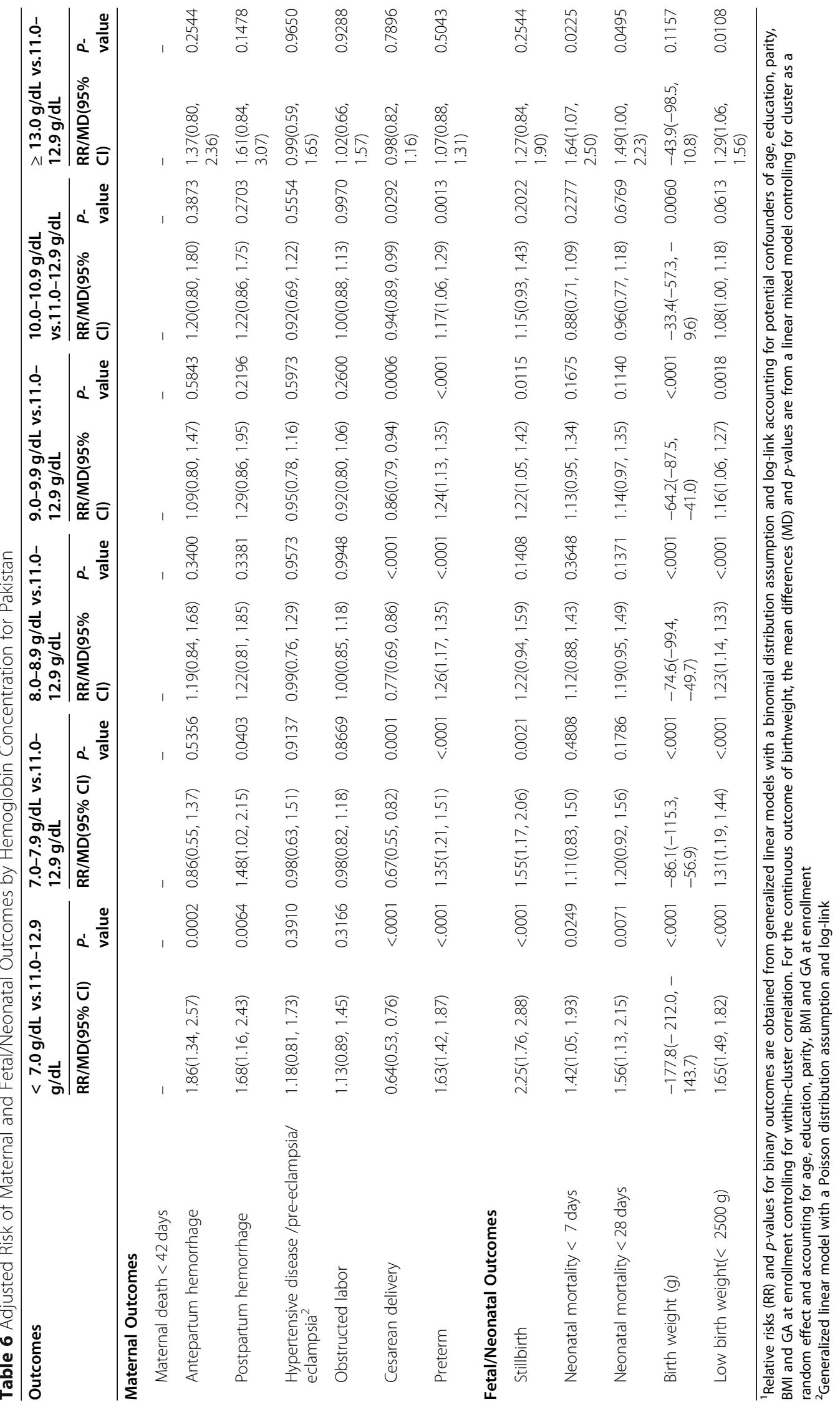




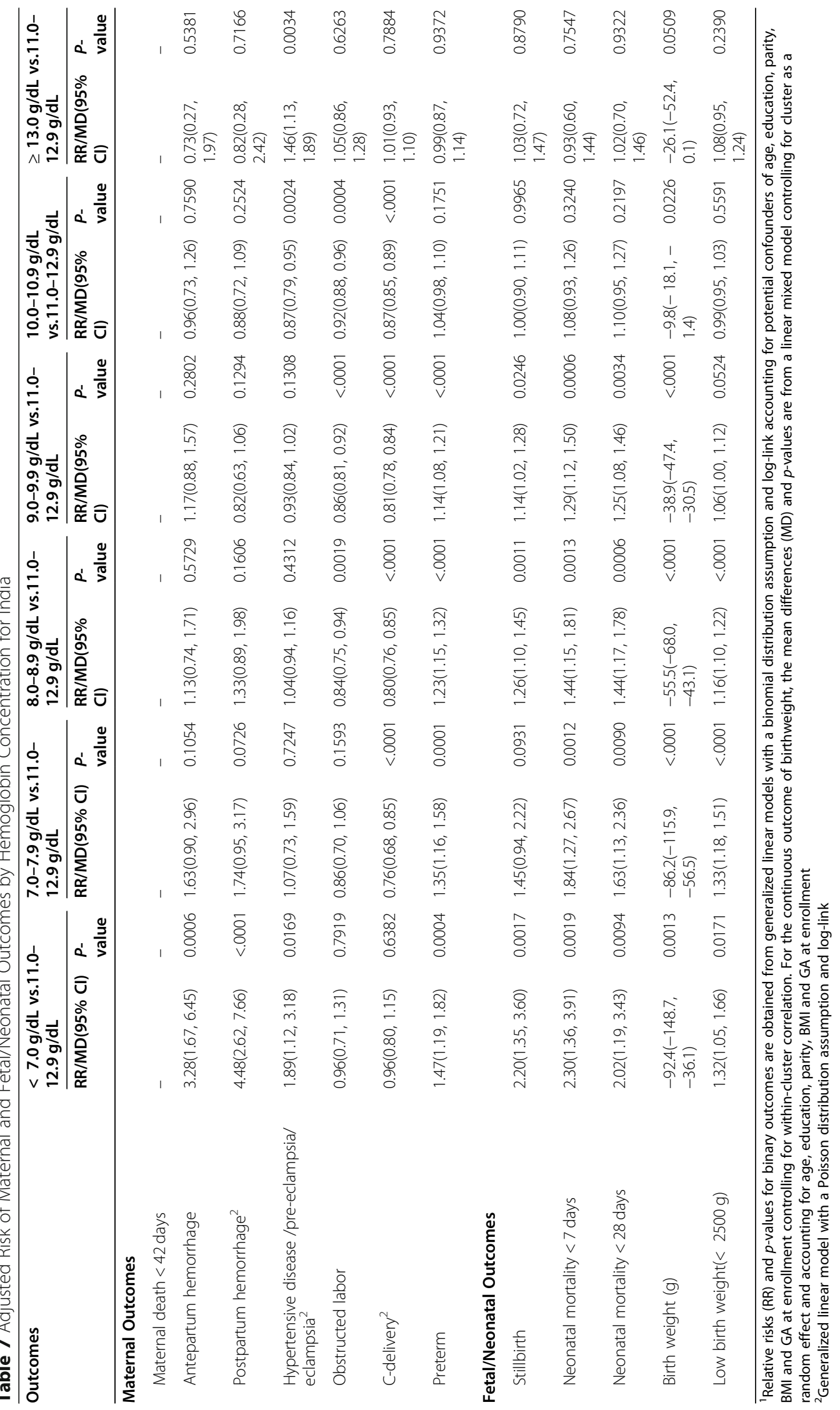




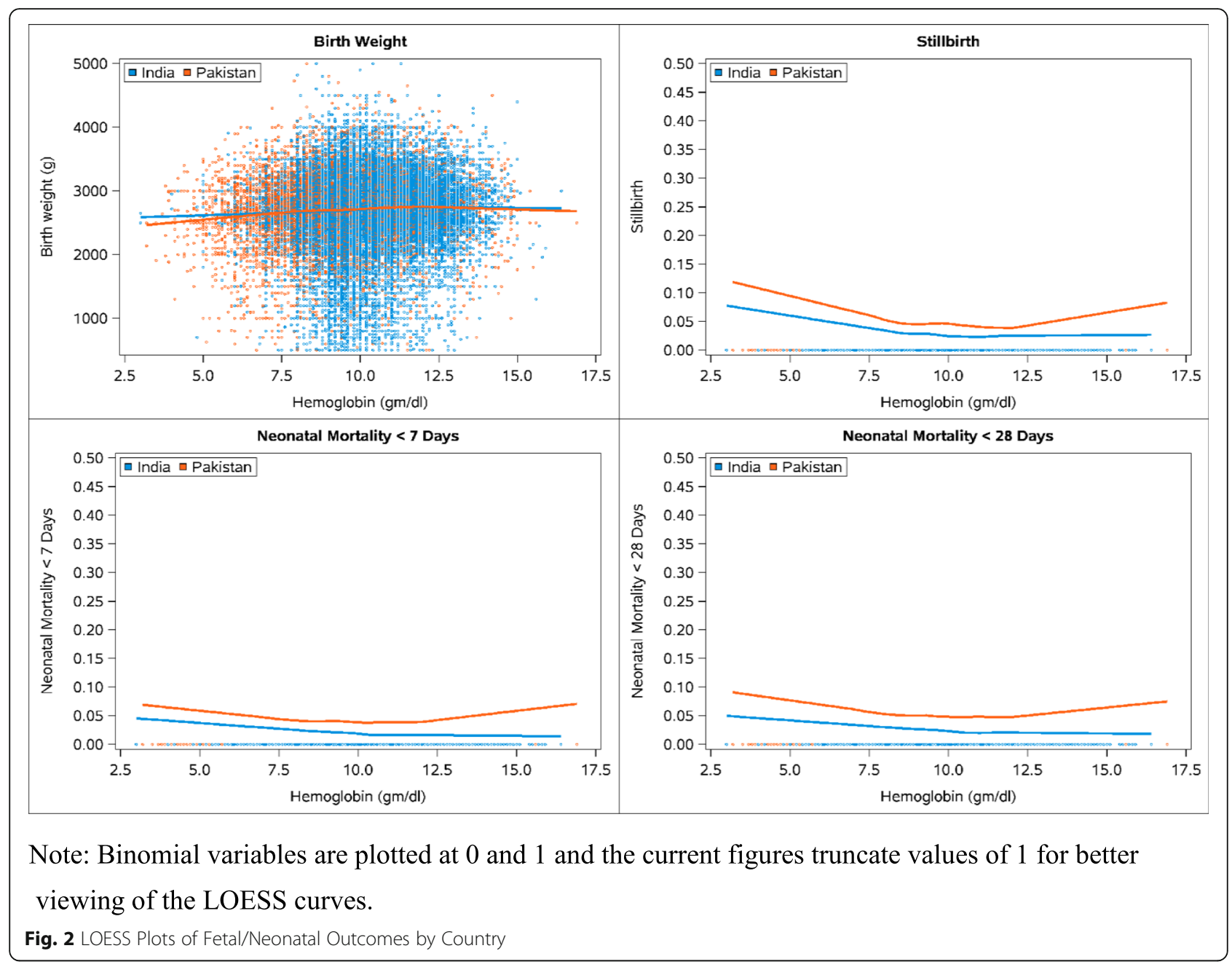

neonatal outcomes in South Asian populations in India and Pakistan. Despite these strengths, our study had some limitations. First, only $29 \%$ of the Pakistani women had a $\mathrm{Hb}$ measured. There were also some differences in the women with $\mathrm{Hb}$ measurements and those without, and although these differences were small, the results may not be generalizable to all women in the study. Also, we did not record the specific gestational age in pregnancy when the $\mathrm{Hb}$ concentrations were measured, although at all sites the $\mathrm{Hb}$ level is taken at the first antenatal visit. Because $\mathrm{Hb}$ concentrations fell slightly as the pregnancy advanced, we adjusted for the gestational age of the first visit to reduce confounding. Another limitation of our study was that our gestational age data and the rates of PTB were generally based on LMP data rather than on a gestational age determined by an early ultrasound. Although there could be bias among those with $\mathrm{Hb}$ data available, we are not aware of any systematic differences in $\mathrm{Hb}$ collection that may have biased the relationships we report.

\section{Conclusions}

Based on our findings, both low and high values of $\mathrm{Hb}$ should be considered risk factors for the mother and fetus. Further research is required to understand the biological processes that underlie our results. In addition, studies are recommended to identify whether the Pakistani women have very low $\mathrm{Hb}$ concentrations due to dietary causes (iron and folic acid deficiencies), paracytic infections, or whether there are some underlying hereditary disorders that might be prevalent among the women such as red cell abnormalities or hemoglobinopathies.

\section{Supplementary information}

The online version contains supplementary material available at https://doi. org/10.1186/s12978-020-01006-6.

Additional file 1: Supplementary Table S1: Socio Demographic and Clinical Characteristics of Pregnant Women by Hemoglobin Availability (DOCX $25 \mathrm{~kb})$ 


\section{Abbreviations}

ANC: Antenatal Care; BMl: Body Mass Index; LBW: Low birth weight; LMIC: Low-middle income countries; MNHR: Maternal Newborn Health Registry; PTB: Preterm birth; RA: Registry Administrator

\section{Acknowledgements}

I would like to acknowledge the study research staff who collected data in the field and to study participants who provided the data to undertake the research study.

\section{About this supplement}

This article has been published as part of Reproductive Health, Volume 17 Supplement 2, 2020: Global Network MNH. The full contents of the supplement are available at https://reproductive-health-journal. biomedcentral.com/articles/supplements/volume-17-supplement-2

\section{Authors' contributions}

SA conceived of the manuscript and wrote the first draft with input from RLG, SST, SS, JLM and EMM. SA, SS, SST, SD, AP, PLH, RJD, RLG, JM and EMM oversaw study implementation, data collection and quality monitoring. JLM and EMM performed the statistical analyses. All authors reviewed and approved the final manuscript.

\section{Funding}

Publication of this supplement was funded by grants from the Eunice Kennedy Shriver National Institute of Child Health and Human Development (U10HD076457, U10HD078438, U01 HD040636).

\section{Availability of data and materials}

Data from the study will be available at the NICHD data repository (N-DASH): https://dash.nichd.nih.gov/

\section{Ethics approval and consent to participate}

This study was reviewed and approved by ethics review committees at KLE Academy of Higher Education and Research's Jawaharal Nehru Medical College, Belagavi; the institutional review board Thomas Jefferson University and the data coordinating center (RTI International). All women provided informed consent for participation in the study, including data collection and the follow-up visits.

\section{Consent for publication}

The article was approved for publication by NICHD through its clearance mechanism.

\section{Competing interests}

The authors declare that they have no competing interests.

\section{Author details}

${ }^{1}$ Department of Community Health Sciences, Aga Khan University, Stadium Road, Karachi 74800, Pakistan. ${ }^{2}$ Lata Medical Research Foundation, Nagpur, India. ${ }^{3}$ Boston University, Boston, MA, USA. ${ }^{4}$ KLE Academy of Higher Education and Research's J N Medical College, Belagavi, India. ${ }^{5}$ Thomas Jefferson University, Philadelphia, PA, USA. ${ }^{6}$ RTI International, Research Triangle Park, Durham, NC, USA. '7Department of Obstetrics and Gynecology, Columbia University, New York, NY, USA

\section{Published: 30 November 2020}

\section{References}

1. Institute for Health Metrics and Evaluation HDN, The World Bank. The global burden of disease (GBD) compare [Internet] ed. Seattle: IHME; 2013. [http:// vizhub.healthdata.org/gbd-compare/]

2. World Health organization. The global prevalence of anaemia in 2011 Geneva: World Health Organization; 2015.

3. Haider BA, Olofin I, Wang M, Spiegelman D, Ezzati M, Fawzi WW. Anaemia, prenatal iron use, and risk of adverse pregnancy outcomes: systematic review and meta-analysis. BMJ (Clinical research ed). 2013;346:f3443.

4. Kalaivani K. Prevalence \& consequences of anaemia in pregnancy. Indian J Med Res. 2009;130(5):627-33.

5. Child Health Epidemiology Reference Group Kozuki Naoko Lee Anne C. Katz Joanne jkatz@ jhsph. edu Author disclosures: N. Kozuki AL, J. Katz ncoi: moderate to severe, but not mild, maternal anemia is associated with increased risk of small-for-gestational-age outcomes. J Nutr. 2012;142(2):358-62.

6. Rahman MM, Abe SK, Rahman MS, Kanda M, Narita S, Bilano V, Ota E, Gilmour S, Shibuya K. Maternal anemia and risk of adverse birth and health outcomes in low- and middle-income countries: systematic review and meta-analysis. Am J Clin Nutr. 2016;103(2):495-504.

7. Randall DA, Patterson JA, Gallimore F, Morris JM, McGee TM, Ford JB. The association between haemoglobin levels in the first 20 weeks of pregnancy and pregnancy outcomes. PLoS One. 2019;14(11):e0225123.

8. Mahmood T, Rehman AU, Tserenpil G, Siddiqui F, Ahmed M, Siraj F, Kumar B. The association between Iron-deficiency Anemia and adverse pregnancy outcomes: a retrospective report from Pakistan. Cureus. 2019;11(10):e5854.

9. Drukker L, Hants Y, Farkash R, Ruchlemer R, Samueloff A, Grisaru-Granovsky S. Iron deficiency anemia at admission for labor and delivery is associated with an increased risk for cesarean section and adverse maternal and neonatal outcomes. Transfusion. 2015;55(12):2799-806.

10. Gonzales GF, Tapia V, Fort AL. Maternal and perinatal outcomes in second hemoglobin measurement in nonanemic women at first booking: effect of altitude of residence in Peru. ISRN Obstet Gynecol. 2012;2012:368571.

11. Garn S, Ridella S, Petzold A, Falkner F. Maternal hematologic levels and pregnancy outcomes. Semin Perinatol. 1981;5(2):155-62.

12. Zhou L-M, Yang W-W, Hua J-Z, Deng C-Q, Tao X, Stoltzfus RJ. Relation of hemoglobin measured at different times in pregnancy to preterm birth and low birth weight in Shanghai, China. Am J Epidemiol. 1998;148(10):998-1006.

13. Murphy J, Newcombe R, O'riordan J, Coles E, Pearson JJTL: Relation of haemoglobin levels in first and second trimesters to outcome of pregnancy 1986, 327(8488):992-995.

14. Steer P, Alam MA, Wadsworth J, Welch AJB: Relation between maternal haemoglobin concentration and birth weight in different ethnic groups 1995, 310(6978):489-491.

15. Hämäläinen $\mathrm{H}$, Hakkarainen $\mathrm{K}$, Heinonen SJCN: Anaemia in the first but not in the second or third trimester is a risk factor for low birth weight 2003, 22(3):271-275.

16. Scanlon KS, Yip R, Schieve LA, Cogswell ME. High and low hemoglobin levels during pregnancy: differential risks for preterm birth and small for gestational age. Obstet Gynecol. 2000;96(5 Pt 1):741-8.

17. Stephansson O, Dickman PW, Johansson A, Cnattingius S. Maternal hemoglobin concentration during pregnancy and risk of stillbirth. JAMA. 2000;284(20):2611-7.

18. Maghsoudlou S, Cnattingius S, Stephansson O, Aarabi M, Semnani S, Montgomery SM, Bahmanyar S. Maternal haemoglobin concentrations before and during pregnancy and stillbirth risk: a population-based casecontrol study. BMC Pregnancy Childbirth. 2016;16(1):135.

19. Goudar SS, Carlo WA, McClure EM, Pasha O, Patel A, Esamai F, Chomba E, Garces A, Althabe F, Kodkany B, et al. The maternal and newborn health registry study of the global network for women's and children's health research. Int J Gynec Obstetrics. 2012;118(3):190-3.

20. Jaleel R, Khan AJJoSP: Severe anaemia and adverse pregnancy outcome. 2008, 13(4):147.

21. Murphy J, Newcombe R, O'riordan J, Coles E, Pearson J. Relation of haemoglobin levels in first and second trimesters to outcome of pregnancy. Lancet. 1986;327(8488):992-5.

22. Dunlop W, Furness C, Hill L. Maternal HAEMOGLOBIN concentration, HAEM ATOCRIT and renal handling of URATE in pregnancies ending in the births of small-for-dates infants. BJOG Int J Obstet Gynaecol. 1978:85(12):938-40.

23. Mau G. Hemoglobin changes during pregnancy and growth disturbances in the neonate. J Perinat Med. 1977:5(4):172-7.

24. Sagen N, Nilsen ST, Kim HC, Bergsjø P, Roller O. Maternal hemoglobin concentration is closely related to birth weight in normal pregnancies. Acta Obstet Gynecol Scand. 1984;63(3):245-8.

\section{Publisher's Note}

Springer Nature remains neutral with regard to jurisdictional claims in published maps and institutional affiliations. 